\title{
Related Factors With Pneumonia Events In Rsud. Dr. Soedarso Pontianak October Period 2013 - November 2015
}

Ika Avrilina Haryono ${ }^{1 *}$

${ }^{1}$ High School of Health Sciences Sari Mulia, Banjarmasin Indonesia

*Ika.avrilina@stikessarimulia.ac.id

Anggrita Sari ${ }^{2}$

${ }^{2}$ Midwifery Academy Sari Mulia, Banjarmasin Indonesia

anggritasariangel@gmail.com

Yayuk Puji Lestari ${ }^{1}$

${ }^{1}$ High School of Health Sciences Sari Mulia, Banjarmasin Indonesia yayuk.pujilestari1892@gmail.com

Mega Yunita Sari ${ }^{2}$

${ }^{2}$ Midwifery Academy Sari Mulia, Banjarmasin Indonesia

mega_yunita@akbidsarimulia.ac.id

\begin{abstract}
Objective: To analyze factors related to the incidence of pneumonia in dr. Soedarso Pontianak period of October 2013 - November 2015.

Methods: Design research with quantitative observational using case-control studies. The subjects of the study were case group of under-five children diagnosed with pneumonia and control group ie under-five children who were not diagnosed with pneumonia who were hospitalized in RSUD dr. Soedarso Pontianak, where the number of samples in the case group as many as 301 samples and the control group as many as 301 samples.

Results: The study used logistic regression analysis. The results showed that most factors related to the incidence of pneumonia were age, where ( $\mathrm{p}$ value $=0,000$ and OR 27,95), nutritional status ( $\mathrm{p}$ value $=0,000$ and OR 19.56), history of ASI ( $\mathrm{p}$ value $=0,000$ and OR 5,58), BBL ( $\mathrm{p}$ value $=0,000$ and OR 3.24), while measles immunization status was significantly inverted (p value 0,007 and OR $0,370)$. DPT immunization status counfounding on age variable with $\mathrm{OR}>10 \%$.

Conclusions: The variables most associated with the incidence of pneumonia are age, nutritional status, history of breastfeeding and BBL, while measles immunization status variables are significantly related to children who get measles immunization riskier than toddlers who do not get measles immunization.
\end{abstract}

Keywords: Age, Birth Weight, Breast Milk, Nutritional Status, Pneumonia.

\section{INTRODUCTION}

Acute Respiratory Infection (ARI) is a common diseases in children. ARI is also one of the main causes of patient visits in health facilities. One of the ARD of ARI which is the target of ARD prevention program is pneumonia. Pneumonia is an acute respiratory infection of the lung parenchyma. The inflammation is caused by one or more agents following viruses, bacteria, mycoplasma and 
the aspiration of foreign substances and the leading cause of death in infants in the world. The global disease can be overcome in developed countries, but quite fatal in developing countries [1].

Acute Respiratory Infections (ARI) in children less than five years old are the leading cause of childhood mortality in the world. Most of these deaths are caused by pneumonia and bronchiolitis. WHO estimated that the annual number of ARI-related deaths in this age group (excluding those caused by measles and pertussis and neonatal deaths) was 2.1 million [2], accounting for about $20 \%$ of all childhood deaths [3].

About 156 million new episodes of childhood clinical pneumonia occurred globally in 2000 , more than $95 \%$ of them in developing countries. Of all the pneumonia cases occurring in those countries, $8.7 \%$ are severe enough to be life-threatening and require hospital admission. About 2 million pneumonia deaths occur each year in children aged less than 5 years, mainly in the African and South-East Asia Regions. The main bacterial causes of clinical pneumonia in developing countries are S. pneumoniae and Hib, and the main viral cause is a respiratory syncytial virus, but estimates of their relative importance vary in different settings. The only vaccines for the prevention of bacterial pneumonia (excluding pertussis) are $\mathrm{Hib}$ and pneumococcal vaccines [4].

In Indonesia, based on the results of Basic Health Research (Riskerdas) in 2013 showed period prevalence and prevalence of $1.8 \%$ and 4.5\%. The five provinces with the highest incidence of pneumonia were East Nusa Tenggara (38.5 \%), Aceh (35.6\%), Bangka Belitung (34.8\%o), West Sulawesi (34.8\%o) and Central Kalimantan (32,7\%) [27]. Period prevalence pneumonia in Indonesia in 2013 decreased compared to 2007. The highest incidence of childhood pneumonia was consecutive in the 12-23 month age group (21.7\%), followed by age group 24-35 months (21\%), age group $36-47$ months (18.2\%), age group 48-59 months (17.9\%) and the lowest in the age group 0-11 months (13.6\%) [5].

According to data from Ditjen PP and PL, Kemenkes RI (2015), from 2,231,138 pneumonia discovery target in Indonesia, there are 657,490 cases or $(29,47 \%)$ of children under five suffering from pneumonia. While in West Kalimantan province there are 2443 cases or $(5.21 \%)$ who experienced pneumonia from the target of pneumonia toddler discovery as much as 46.895 [6].

Furthermore, in the city of Pontianak in 2012 the prevalence of pneumonia is $15.01 \%$ of 5503 children under five. In 2013 the incidence of pneumonia increased to $22.1 \%$ from 5596 toddlers. Exchange difference due to the translation of financial statements. This shows the incidence of pneumonia in Pontianak is still quite high every year $[6,7,8]$.

The risk factors that influence the occurrence of pneumonia among children are age, sex, nutritional status, immunization status, lack of breastfeeding, vitamin A 
deficiency, lack of zinc supplementation, low birth weight baby, and air pollution and other factors that can increase incidence of pneumonia is maternal education, economic status, toddler age and occupancy density.

Regional General Hospital (RSUD) dr. Soedarso Pontianak is a class B country hospital which is also one of the regional hospital as well as the highest referrals in West Kalimantan, so patients in hospitals dr. Soedarso Pontianak can represent most of the pneumonia sufferer in Pontianak city. Based on hospital annual report dr. Soedarso Pontianak there are 128 cases of pneumonia in infants in 2012, fell to 117 cases in 2013. In 2014 There was a significant increase from the previous only 117 cases to 169 cases. The purpose of this study is to determine the factors associated with the incidence of pneumonia in infants in hospitals dr. Soedarso Pontianak.

\section{RESEARCH METHOD}

This research is quantitative analytic observational by type. The population in the study were all under-fives recorded in medical report records inpatient hospital in $\mathrm{dr}$. Soedarso Pontianak period October 2013 November 2015. Determination of the sample size in this study is by using hypothesis test for Odds Ratio [9], with 5\% significance degree and $90 \%$ test strength [10], and the large difference of 301 case samples and 301 until control. This study uses documentation study instrument. Independent variables in this study: nutritional status, history of breastfeeding, DPT immunization status, Measles Immunization status, LBW, Age, sex, while the dependent variable is the incidence of pneumonia in infants. Data analysis by Univariate, Bivariate, and Multivariate.

\section{RESULTS}

1. Univariate Analysis

Based on the result of univariate analysis shown in Table 1, it was found that there were less than 228 children under five years old $(37,9 \%)$, non-exclusive breastfeeding of 255 infants $(42,4 \%)$, toddler with complete DPT immunization status 240 39,9\%), toddler with incomplete measles immunization status as many as 346 children under five $(57,5 \%)$, toddlers who have Birth Weight <2500 gram there are $199(33,1 \%)$, toddler age $\leq 12$ months there are $380(63,1 \%)$, and toddler with male gender as much as $328(54,5 \%)$. For more details can be seen on the resume table 1 below: 
Table 1 does not show any homogeneous variable that is an independent variable which one of them has value $<15 \%$.

Table 1. characteristics of children aged 0-60 month

\begin{tabular}{|c|c|c|c|}
\hline No & Variable dan Kategori & Frequency & Percentage \\
\hline \multirow[t]{4}{*}{1} & Nutrition Status & & \\
\hline & Nutrition less & 228 & 37,9 \\
\hline & Good Nutrition & 374 & 62,1 \\
\hline & Total & 602 & 100 \\
\hline \multirow[t]{4}{*}{2} & History Breast Milk & & \\
\hline & Not Exclusive & 255 & 42,4 \\
\hline & Exclusive & 347 & 57,6 \\
\hline & Total & 602 & 100 \\
\hline \multirow[t]{4}{*}{3} & DPT Immunization Status & & \\
\hline & Not Complete & 240 & 39,9 \\
\hline & Complete & 362 & 60,1 \\
\hline & Total & 602 & 100 \\
\hline \multirow[t]{4}{*}{4} & Measles Immunization Status & & \\
\hline & Never & 346 & 57,5 \\
\hline & Ever & 256 & 42,5 \\
\hline & Total & 602 & 100 \\
\hline \multirow[t]{4}{*}{5} & Birth Weight & & \\
\hline & $<2500$ grams & 199 & 33,1 \\
\hline & $\geq 2500$ grams & 403 & 66,9 \\
\hline & Total & 602 & 100 \\
\hline \multirow[t]{4}{*}{6} & Toddlers Age & & \\
\hline & $\leq 12$ Months & 380 & 63,1 \\
\hline & $13-59$ Months & 222 & 36,9 \\
\hline & Jumlah & 100 & 100 \\
\hline \multirow[t]{4}{*}{7} & Gender & & \\
\hline & Male & 328 & 54,5 \\
\hline & Female & 274 & 45,5 \\
\hline & Total & 602 & 100 \\
\hline
\end{tabular}

\section{Bivariate Analysis}

Table 2. Result Bivariat Analysis

\begin{tabular}{|c|c|c|c|c|c|c|c|c|}
\hline \multirow{3}{*}{ Variable } & \multicolumn{6}{|c|}{ Pneumonia } & \multirow{3}{*}{$\underset{\text { Value }}{\mathbf{P}}$} & \multirow{3}{*}{$\begin{array}{c}\text { OR }(95 \% \\
\text { CI })\end{array}$} \\
\hline & \multicolumn{2}{|c|}{ Case } & \multicolumn{2}{|c|}{ Control } & \multicolumn{2}{|c|}{ Total } & & \\
\hline & $\mathrm{N}$ & $\%$ & $\mathrm{~N}$ & $\%$ & $\mathrm{~N}$ & $\%$ & & \\
\hline \multicolumn{9}{|c|}{ Nutrition Status } \\
\hline Less & 185 & 61,5 & 43 & 14,3 & 228 & 37,9 & \multirow{3}{*}{$\begin{array}{l}.00 \\
0\end{array}$} & \multirow{3}{*}{$\begin{array}{l}9.569 \\
(6.430- \\
14.241)\end{array}$} \\
\hline Good & 116 & 38,5 & 258 & 85,7 & 374 & 62,1 & & \\
\hline Total & 301 & 50 & 301 & 50 & 602 & 100 & & \\
\hline \multicolumn{9}{|c|}{ History Breast Milk } \\
\hline Not Exlusive & 175 & 58,1 & 80 & 26,6 & 255 & 42,4 & \multirow{3}{*}{$\begin{array}{c}.00 \\
0\end{array}$} & \multirow{3}{*}{$\begin{array}{c}3,837 \\
(2.722- \\
5,408)\end{array}$} \\
\hline Exlusive & 126 & 41,9 & 221 & 73,4 & 347 & 57,6 & & \\
\hline Total & 301 & 50 & 301 & 50 & 602 & 100 & & \\
\hline \multicolumn{9}{|c|}{ DPT Immunization Status } \\
\hline $\begin{array}{c}\text { Not } \\
\text { Complat }\end{array}$ & 152 & 51,2 & 86 & 28,6 & 240 & 39 & \multirow{4}{*}{.000} & \multirow{4}{*}{$\begin{array}{c}2,619 \\
(1,870- \\
3,669)\end{array}$} \\
\hline Complete & & & & & & $\begin{array}{l}9 \\
60\end{array}$ & & \\
\hline Complete & 147 & 48,8 & 215 & 71,4 & 362 &, 1 & & \\
\hline Total & 301 & 50 & 301 & 50 & 602 & $\begin{array}{c}10 \\
0\end{array}$ & & \\
\hline \multicolumn{9}{|c|}{ Measles Immunization Status } \\
\hline Never & 191 & 63,5 & 155 & 51,5 & 346 & 57,5 & \multirow{3}{*}{$\begin{array}{c}.00 \\
4\end{array}$} & \multirow{3}{*}{$\begin{array}{c}1,636 \\
(1,181- \\
2,265)\end{array}$} \\
\hline Ever & 110 & 36,5 & 146 & 48,5 & 256 & 42,5 & & \\
\hline Jumlah & 301 & 50 & 301 & 50 & 602 & 100 & & \\
\hline \multicolumn{9}{|l|}{ Birth Weight } \\
\hline$<2500$ grams & 148 & 49,2 & 51 & 16,9 & 199 & 33,1 & \multirow{3}{*}{$\begin{array}{c}.00 \\
0\end{array}$} & \multirow{3}{*}{$\begin{array}{c}4,742 \\
(3,254- \\
6,910)\end{array}$} \\
\hline$\geq 2500$ grams & 153 & 50,8 & 250 & 83,1 & 403 & 66,9 & & \\
\hline Total & 301 & 50 & 301 & 50 & 602 & 100 & & \\
\hline \multicolumn{9}{|l|}{ Age } \\
\hline$\leq 12$ months & 244 & 81,1 & 136 & 45,2 & 380 & 63,1 & \multirow{3}{*}{$\begin{array}{c}.00 \\
0\end{array}$} & \multirow{3}{*}{$\begin{array}{c}5,193(3,598 \\
-7.496)\end{array}$} \\
\hline $\begin{array}{l}13-59 \\
\text { months }\end{array}$ & 57 & 18,9 & 165 & 54,8 & 222 & 36,9 & & \\
\hline Total & 301 & 50 & 301 & 50 & 602 & 100 & & \\
\hline \multicolumn{9}{|l|}{ Gender } \\
\hline Male & 169 & 56,1 & 159 & 52,8 & 328 & 54,5 & \multirow{3}{*}{$\begin{array}{c}.46 \\
1\end{array}$} & \multirow{3}{*}{$\begin{array}{c}1.143 \\
(0,829- \\
1.576)\end{array}$} \\
\hline Female & 132 & 43,9 & 142 & 47,2 & 274 & 45,5 & & \\
\hline Jumlah & 301 & 50 & 301 & 50 & 602 & 100 & & \\
\hline
\end{tabular}

Based on Table 2 It can be seen that from 7 independent variables, significantly related to the incidence of pneumonia is nutritional status, history of milk, immunization status of DPT, immunization status of measles, BBL and age.

\section{Multivariate Analysis}

a. Bivariate Selection

From the result of bivariate selection that has been done, only gender variables are not included in multivariate modeling because it has $p>0.25$. The result of bivariate selection for a multivariate candidate can be seen in the following table:

Table 3. Results of Bivariate Selection For Multivariate candidates $(\mathrm{p}<0.25)$

\begin{tabular}{llcl}
\hline No & \multicolumn{1}{c}{ Variable } & P Value & \multicolumn{1}{c}{ OR } \\
\hline 1 & Nutritional status & 0,000 & Candidate \\
2 & Breastfeeding history & 0,000 & Candidate \\
3 & DPT Immunization & 0,000 & Candidate \\
& Status & 0,004 & Candidate \\
4 & Measles & & \\
& Immunization Status & 0,000 & Candidate \\
5 & Birth Weight & 0,000 & Candidate \\
6 & Age of toddler &
\end{tabular}

b. Multivariate Modeling

After multivariate analysis of 6 independent variables with the incidence of pneumonia, the multivariate analysis of modeling 1 as shown in the table as follows:

\begin{tabular}{clcccc}
\multicolumn{2}{c}{ Table 4. Multivariate Modeling (Model 1) } \\
\hline No & \multicolumn{1}{c}{ Variable } & P & OR & \multicolumn{2}{c}{$(95 \%$ CI) } \\
\cline { 5 - 6 } & & Value & & Lower & Upper \\
\hline 1 & Age of toddler & 0.000 & 27,95 & 12,73 & 61,36 \\
2 & Nutritional status & 0.000 & 19,559 & 10,89 & 35,13 \\
3 & Breastfeeding & 0.000 & 5,576 & 3,399 & 9,15 \\
& history & & & & \\
4 & BBL & 0.000 & 3,244 & 1,974 & 5,331 \\
5 & DPT & $\mathbf{0 , 1 2 0}$ & 0.880 & 1,601 & 5,331 \\
& $\begin{array}{l}\text { immunization } \\
\text { status }\end{array}$ & & & & \\
6 & $\begin{array}{l}\text { Status of measles } \\
\text { immunization }\end{array}$ & 0.007 & 0.370 & 0.181 & 0.760 \\
& & & & &
\end{tabular}


Table 4 shows that there is 1 independent variable with $p>0,05$ that is variable of DPT immunization status history. Variables with $p>0,05$ were excluded from the next multivariate model gradually starting from the highest p-value. It can be seen from table 4 that the largest $p$-value is DPT immunization status variable, so DPT immunization status variable is removed from the second modeling, then the result is as shown in the following table:

Table 5. Multivariate Modeling (Model 2)

\begin{tabular}{llcccc}
\hline No & \multicolumn{1}{c}{ Variable } & P & OR & \multicolumn{2}{c}{$(95 \%$ CI $)$} \\
\cline { 5 - 6 } & & Value & & Lower & Upper \\
\hline 1 & Age of toddler & 0.000 & 30,87 & 14,15 & 67,37 \\
2 & Nutritional & 0.000 & 19,81 & 11,03 & 35,6 \\
& status & & & & \\
3 & Breastfeeding & 0.000 & 5,581 & 3,41 & 9,14 \\
& history & & & & \\
4 & BBL & 0.000 & 3,448 & 2,11 & 5,64 \\
5 & Status of & 0.023 & 0.470 & 0.25 & 0.90 \\
& $\begin{array}{l}\text { measles } \\
\text { immunization }\end{array}$ & & & & \\
\hline
\end{tabular}

Table 5 shows that after the second modeling, it is then seen that the OR value of OR before OR variable $\mathrm{X}$ is issued - OR after $\mathrm{X}$ variable is issued / OR before $\mathrm{X}$ variable is issued $\mathrm{X}$ $100 \%)$ on another independent variable with or without DPT immunization status is in the table as follows:

Table 6. OR changes with and without DPT immunization Variables (Model 2).

\begin{tabular}{llccc}
\hline No & \multicolumn{1}{c}{ Variable } & $\begin{array}{c}\text { OR with } \\
\text { DPT } \\
\text { immunizatio } \\
\text { n status } \\
\text { variable }\end{array}$ & $\begin{array}{c}\text { OR without } \\
\text { the DPT } \\
\text { immunizatio } \\
\text { n status } \\
\text { variable }\end{array}$ & $\begin{array}{c}\text { OR } \\
\text { Changes } \\
(\mathbf{\%})\end{array}$ \\
\hline $\mathbf{1}$ & Age of toddler & 27,953 & 30,870 & $\mathbf{1 0 , 4 4}$ \\
$\mathbf{2}$ & Nutritional status & 19,56 & 19,81 & 1,28 \\
$\mathbf{3}$ & Breastfeeding & 5,576 & 5,581 & 0,09 \\
$\mathbf{4}$ & history & 3,244 & 3,448 & 6,3 \\
$\mathbf{5}$ & BBL & 0.376 & 0.470 & $\mathbf{2 5}$ \\
& Status of measles & & & \\
& immunization & & & \\
\hline
\end{tabular}

From table 6 above, there are 2 changes of OR $>10 \%$, on age variable and status of measles immunization when DPT immunization status variable is issued. Thus the DPT immunization status variable is confounding with age variable and immunization status of measles. then the DPT immunization status variable is re-entered into multivariate analysis model. The final result of the multivariate analysis in the table as follows:

Table 7. Multivariate Modeling (Model 3)

\begin{tabular}{|c|c|c|c|c|c|c|}
\hline \multirow[t]{2}{*}{ No } & \multirow[t]{2}{*}{ Variable } & \multirow{2}{*}{$\begin{array}{c}\mathrm{P} \\
\text { Value }\end{array}$} & \multirow[t]{2}{*}{ OR } & \multicolumn{2}{|c|}{$(95 \% \mathrm{CI})$} & \multirow{2}{*}{$\begin{array}{l}\text { Negelke } \\
\text { rke R } \\
\text { Square }\end{array}$} \\
\hline & & & & Lower & Upper & \\
\hline 1 & Age of toddler & 0.000 & 27,9 & 12,73 & 61,36 & \\
\hline 2 & $\begin{array}{l}\text { Nutritional } \\
\text { status }\end{array}$ & 0.000 & 19,6 & 10,89 & 35,13 & \\
\hline 3 & $\begin{array}{l}\text { Breastfeeding } \\
\text { history }\end{array}$ & 0.000 & 5,6 & 3,39 & 9,15 & \\
\hline 4 & BBL & 0.000 & 3,2 & 1,97 & 5,33 & 614 \\
\hline 5 & $\begin{array}{l}\text { DPT } \\
\text { immunization } \\
\text { status }\end{array}$ & 0,120 & 0.9 & 1,6 & 5,33 & \\
\hline 6 & $\begin{array}{l}\text { Status of } \\
\text { measles } \\
\text { immunization }\end{array}$ & 0.007 & 0.37 & 0.18 & 0.76 & \\
\hline
\end{tabular}

Table 7 shows that the variables significantly associated with the incidence of pneumonia are:

1. Age of toddler

Toddlers with age $\leq 12$ months are 28 times more likely to have pneumonia compared to under-fives aged 13 - 59 months (95\% CI: OR $=12.7-61.4)$. The variables confounding with age where the history of DPT immunization.

2. Nutritional status

Toddlers with nutritional status approximately 20 times more likely to experience pneumonia than toddlers with good nutritional status. $(95 \%$ CI: OR $=10,89-35,13)$.

\section{Breastfeeding history}

Toddlers who did not get exclusive breastfeeding for 6 months were 6 times more likely to have pneumonia compared to infants 
who had received exclusive breastfeeding for 6 months (95\% CI: OR =3,4 - 9,15).

\section{Birth Weight}

Toddlers with a history of low birth weight $<2500$ grams are at risk 3 times more likely to have pneumonia compared with children with a normal birth weight of $\geq 2500$ grams (95\% CI: OR $=2-5.3)$.

5. The status of measles immunization is significantly associated with the incidence of pneumonia. Because it has OR $<1-<1(95 \%$ $\mathrm{CI}: \mathrm{OR}=0.2-0.8)$.

6. Based on the multivariate analysis on the last model, the value of Nagelkerke $R$ Square is 0.614 , it can be said that from 4 independent variables that related to age, nutritional status, history of milk and BBL, can only explain $61,4 \%$ from incidence of pneumonia while the rest $38,6 \%$ explained by other related variables.

\section{DISCUSSION}

a. Independent Variables Associated with Pneumonia Occurrence

1. Age

In this study, it was found that the age of under-fives related cause with the incidence of pneumonia: age $\leq 12$ months had 28 times effect on the incidence of pneumonia in infants compared with age 13 months to 59 months. In relation to it found there is one variable of confounding that is DPT immunization status.

Age is one of the risk factors of death in infants suffering from pneumonia. The high incidence of pneumonia mainly affects infant and toddler age groups. Newborns are the most vulnerable groups who are susceptible to contracting pneumonia from their mothers through the birth canal during labor, this is because the membranes rupture prematurely, resulting in the fetus being submerged amniotic fluid (amnionitis), then inhaling into the lungs.

Also found supporting theories. According to MOH RI (2004) children aged 024 months are more susceptible to pneumonia than children aged over 2 years. This is due to imperfect immunity and relatively narrow respiratory tract [11].

The results of this study were consistent with Susi's (2012) study which suggested a relationship between age and pneumonia where under-12-year-olds had a 3.24-fold chance of experiencing pneumonia compared with under-fives aged> $12-<60$ months. Infants and toddlers have a body defense mechanism that is still weak compared to adults, so toddlers fall into groups prone to infections such as influenza and pneumonia. In addition, preterm babies (gestational age $<37$ weeks) have a high risk of diseases associated with CNS immaturity (Central Nervous System) and lungs, among others, aspiration pneumonia due to reflexes suck, swallow, and cough is not perfect and syndrome an idiopathic respiratory disorder (hyaline membrane disease) [12].

Other studies mentioned the highest age in under-fives under 2 years [13]. The smaller the 
age of children the more susceptible to infection because the immune system in children aged one year until the age of five years is still immature. The susceptibility of infections in toddlers is also lower than in older children [14].

\section{Nutritional status}

In this study it was found that nutritional status was associated with causation of pneumonia: nutritional status was less affected 20 times to the incidence of pneumonia in infants compared with good nutrition.

The nutritional status of children under five is measured by Age (U), body weight (BB), and height (TB). The BB and TB / PB variables are presented in three anthropometric indexes: BB / U, TB / U, BB / TB. Nutritional status is less cause the body's resistance decreases and pathogen virus infection becomes stronger so that will cause balance disturbed and will happen infection. One of the main determinants in maintaining such a balance is good nutritional status. Toddlers with less nutrition will be more susceptible to pneumonia than toddlers with normal nutrition due to immune factors are lacking. Infectious diseases alone will cause toddlers have no appetite and lead to malnutrition, resulting in a reciprocal relationship between nutritional status and infectious diseases. Under-fives with malnutrition and poor nutrition increase the risk of pneumonia in infants [15].

The results of Sunyataningkamto, et al found that children with malnutrition had a 2.6 times greater risk of pneumonia than children with good nutrition, it was said that malnutrition would decrease the immune capacity to respond to pneumonia infections such as granulocyte function disruption, reduction of complementary function, and also causes, micronutrient deficiency [16]. Other research that is in line is the research conducted in the Work Area Puskesmas Kedungmundu Semarang City showed that children with a history of nutritional status under the red line have a possibility of 10.846 times to suffer from pneumonia compared with a toddler with a history of nutritional status on the red line [17].

In the study of Domili et al, there is a relationship between nutritional status and the incidence of pneumonia in infants. Toddlers tend not to have an appetite that affects malnourishment and malnutrition [18]. A poor and poor nutritional status can cause immune system disturbance. The cells present in the immune system are present in tissues and specific organs of lymphoid tissue as immune tissue.

3. History of breast milk

In this study, it was found that the history of breastfeeding related cause with the incidence of pneumonia: exclusive breastfeeding affects 4 times against the incidence of pneumonia in infants compared with those who get exclusive breastfeeding.

Breast milk is a natural food that is good for babies, contains the ideal nutrients in accordance with the needs and digestive abilities of infants. In breast milk contain 
lactose is higher than artificial milk. Lactose will be fermented into lactic acid which one of them serves to inhibit the growth of pathogenic bacteria and stimulate the growth of microorganisms that can produce organic acids and synthesize some types of vitamins. Breast milk also contains protective substances (antibodies) that can protect the baby during the first 5-6 months, such as: immunoglobin, lysozyme, complements C3 and C4, antistapiloccocus, Lactobacillus, Bifidus, and lactoferrin, this content can provide antibodies to babies and avoid babies of infectious diseases such as pneumonia [19].

Health Act no.36 of 2009 Article 128 paragraph 1 on exclusive breastfeeding explains that every infant is entitled to exclusive breast milk since birth for 6 (six) months unless there is a medical indication [20]. Infants under 6 months of age who were not exclusively breastfed were 5 times at risk of dying from pneumonia compared to infants exclusively breastfed for the first six months of life [21].

The research result of Susi Hartati in Pasar Rebo Jakarta explains that exclusive breastfeeding has significant relation with pneumonia incidence with $\mathrm{OR}=4,47$ value where children who are not exclusively breastfed have a chance of having pneumonia 4.47 times compared to children who get exclusive breastfeeding [12].

As it is known that the function of breast milk that is as an anti-infection that can affect changes in the status of growth in infants and also the length of breastfeeding is lacking and feeding or formula milk too early can increase infections such as diarrhea and ARI. Breast milk has a lot of nutritional effects toddlers that can form a normal growth and also breast milk is needed by infants to provide food at an early age, but the growth of a lot of people affected by food intake at the time of growth.

This is also in line with research conducted by Widarini et al that there is a significant relationship between exclusive breastfeeding and exclusive breastfeeding with the incidence of ARI with $\mathrm{OR}=4,960$ where children who are not exclusively breastfed have a chance of having ISPA 5 times compared to children who get Exclusive breastfeeding [22].

Exclusive breastfeeding provides all the energy and nutrients that are beneficial to the baby's survival, growth, and development. In addition, exclusive breastfeeding can reduce the infant mortality rate caused by various diseases common to children such as diarrhea and pneumonia, and speed recovery when sick and help make birth.

\section{BBL}

In this study found that BBL cause-effect with the incidence of pneumonia: BBL $<2500$ grams effect 3.2 times with the incidence of pneumonia in infants compared to $\mathrm{BBL} \geq$ 2500 grams. No confounding variable was found against the BBL variable.

Babies with LBW, have an immune substance that is not perfect, so it is more susceptible to infection. Babies born with 
LBW will have a higher risk of death than normal-born babies in the first few months of birth because the formation of immune substances is less than perfect, so it is more susceptible to infectious diseases, especially the respiratory tract and pneumonia (Molyneux, 1996).

This is in accordance with the results of research conducted by Dawn showed that LBW is a risk factor for the occurrence of pneumonia in infants aged 0-2 months with the value of OR for the occurrence of LBW is 4.136 with $95 \%$ CI $(1,234-13,869)$. This value means that infants with LBW are 4.2 times more likely to have pneumonia than normalborn birth babies [23].

The results of this study are also in line with research on "The relationship between the characteristics of children under five with ARI occurrence in children in Gandong Village Kaloran District Temanggung Regency" which results say that there is a relationship between BBL <2500 grams with the incidence of ARI in toddlers in Gandon Village $(p=0,002)$. It can be seen that BBL <2500 gram has a risk 15,294 times greater for ARI than toddlers with $\mathrm{BBL} \geq 2500$ gram [24]. LBW in infants will have an effect on the baby in the form of resistance to low infectious diseases, growth, and development of the body more slowly, mortality rate higher than babies who were born with enough weight [25].

But the results of this study are not in line with a study entitled "Analysis of Intrinsic Risk Factors Associated With Pneumonia in
Toddlers in the Working Area of Puskesmas Andalas Kota Padang" states that there is no association between a history of low birth weight $(p$-value $=0.318)$ Pneumonia in infants at Puskesmas Andalas Padang City Year 2016. $\mathrm{OR}=2,545 ; 95 \% \mathrm{CI}=0.620-10.458$ which means that a toddler with a history of low birth weight has a probability of 2,545 times for Pneumonia compared with a toddler who has a normal birth weight history [26]. The result of this research is supported by research of Siska Tambunan, et al which states that the birth weight of children under five is not related to the incidence of pneumonia in toddlers ( $\mathrm{p}$ value $=0.061)$, but the chance is 2.8 times experienced Pneumonia. The absence of any association between the low birth weight of under-fives and the incidence of pneumonia in infants in this study may be due to nutritional status, immunization status, breastfeeding status or extrinsic factors studied [17]

Babies born with LBW will have a higher risk of death than babies with normal birth weight in the first months of birth because of the formation of immune substances are less than perfect, so it is more susceptible to infectious diseases, especially respiratory infections, and pneumonia.

The risk of illness to the risk of death in Low Birth Weight (LBW) is usually problematic because of the growth disorders and immaturity of the organ that can affect the development and health status. In infants LBW, because not yet perfect tools in the body, so the baby can not do the formation of 
anti-immune substances, this is what causes infants susceptible to infections and disorders including respiratory disorders (pneumonia), because the breathing muscles are still weak.

In addition, premature toddlers (gestational age <37 weeks) have a high risk of disease associated with immaturity of the central nervous system and lungs. Generally, less than monthly infant immunity is lower than term infant. Immunoglobulin transport through the placenta mainly occurs in the last half of the third trimester. After birth, serum immunoglobulin concentrations continue to decline, leading to severe hypogammaglobulinemia. Skin immaturity also weakens the skin's defenses. Neonates may develop specific IgG deficiency, especially against streptococcus or Haemophilus influenza. IgG and $\operatorname{IgA}$ do not cross the placenta and are virtually undetectable in cord blood. Given this, the activity of the complement path is delayed, and $\mathrm{C} 3$ and $\mathrm{B}$ are not produced in response to lipopolysaccharide. The combination of immune deficiency and decreased total and specific antibodies, along with a decrease in fibronectin, led to a substantial decrease in opsonization activity.

b. The independent variables are significantly related to the incidence of pneumonia

In this study found that the status of measles immunization correlated significantly with the incidence of pneumonia. Where in the hypothesis, toddlers who do not get measles immunization are more at risk of pneumonia, but in this study found that toddlers who get measles immunization more at risk of experiencing the incidence of pneumonia. According to the researchers' assumptions, this is because children who have had measles immunization if followed by less nutritional status with immune system disorders can cause severe complications in patients, as well as the possibility of selection bias due to errors in selecting samples because the sample was taken at the hospital.

c. Independent variable unrelated to the incidence of pneumonia

In this study, gender was not associated with the incidence of pneumonia. According to the researchers' assumptions, this is because gender is not a direct causal factor. It is said that there are differences in body resistance between boys and girls, but there are other factors that can affect a person's immune system such as lifestyle, environment, food consumed and family habits, it could be other factors that are the direct cause of the incidence of pneumonia. Another possibility of selection bias in the process of data collection.

\section{CONCLUSION}

The variables most associated with the incidence of pneumonia are age, nutritional status, history of ASI and BBL, while measles immunization status variables are significantly inverted where children who get measles immunization are more at risk than toddlers who are not immunized against measles. 


\section{REFERENCES}

[1] Scott JAG, Brooks WA, Perisis JSM, Holtzman. Pneumonia research to reduce childhood mortality in the developing world. 2008; 188(4) (downloaded 2013,20 November). Available at: http:/www.jci.org

[2] Murray CJL, Lopez AD, Mathers CD, Stein C. The global burden of disease 2000 project: aims, methods and data sources. Geneva: World Health Organization; 2001. (Global Programme on Evidence for Health Policy, Discussion Paper No. 36, available at http://www3.who.int/whois/burden/ papers/discussion\%20paper\%2036\%20r evised.doc)

[3] Williams BG, Gouws E, Boschi-Pinto C, Bryce J, Dye C. Estimates of worldwide distribution of child deaths from acute respiratory infections. Lancet Infectious Diseases 2002;2:25-32. availableat:http://www.scielosp.org/sciel o.php?script=sci_arttext\&pid=S004296862004001200005

[4] Igor Rudan, Cynthia Boschi-Pinto, Zrinka Biloglav, c Kim Mulhollandd \& Harry Campbell. Epidemiology and Etiology of Childhood Pneumonia. Bulletin of the World Health Organization 2008;86:408-416. http://dx.doi.org/10.1590/S0042-

96862008000500019 availabel at : http://www.scielosp.org/scielo.php?scrip $\mathrm{t}=$ sci_arttext\&pid=S0042-

$96862008000500019 \& \operatorname{lng}=\mathrm{en} \& \mathrm{nrm}=$ iso \&tlng=en

[5] Kemenkes, RI. Data dan Informasi Tahun 2014 (Profil Kesehatan Indonesia). Kemenkes RI: Jakarta. 2015.

[6] Dinas Kesehatan Provinsi Kalbar. Profil Kesehatan Provinsi Kalimantan Barat Tahun 2012. Depkes RI: Pontianak. 2012.

[7] Dinas Kesehatan Provinsi Kalbar. Profil Kesehatan Kota Pontianak Tahun 2013. Dinkes Kota: Pontianak. 2013.

[8] Dinas Kesehatan Provinsi Kalbar. Profil Kesehatan Kota Pontianak Tahun 2014. Dinkes Kota: Pontianak. 2014.

[9] Lapau, Buchari. Metode Penelitian Kesehatan Metode Ilmiah Penulisan
Skripsi, Tesis, dan Disertasi. 2013. Yayasan Pustaka Obor Indonesia. Jakarta.

[10] Ariawan, I.. Besar dan Metode Sampel Pada Penelitian Kesehatan. Jurusan Biostatistik dan Kependudukan. Fakultas Kesehatan Masyarakat. Universitas Indonesia: Jakarta. 1998.

[11] Depkes RI. Pedoman program pemberantasan penyakit infeksi saluran pernafasan akut (ISPA) untuk penanggulangan pneumonia pada balita. Jakarta. 2004.

[12] Hartati, Susi. Analisis Faktor Resiko Yang Berhubungan Dengan Kejadian Pneumonia Pada Anak Balita di RSUD Pasar Rebo Jakarta. Tesis Magister Ilmu Keperawatan Depok. Universitas Indonesia: Jakarta. 2012. Jurnal Keperawatan Indonesia, Volume 15, No.1, Maret 2012; hal 13-20. http://jki.ui.ac.id/index.php/jki/article/do wnload/42/42

[13] Darwin E. Imunologi dan infeksi. Padang: Andalas University Press. 2006.

[14] Turner C, Turner P, Carrara V, Burgoine $\mathrm{K}$. High risks of pneumonia in children two years of age in South East Asean refugee population. United Kingdom: University College London.2013;8(1):17.

[15] Kartasasmita, Cissy B. Pneumonia pembunuh balita. Dalam: Martin W, Cissy B, Marjanis S, Fransisca HA, Kusbiyanto. Jendela Epidemiology: Pneumonia Balita. Jakarta: Kementrian Kesehatan RI. 2010;3:22.

[16] Sunyataningkamto, dkk. The role of indoor air pollution and other factors in the incidence of pneumonia in underfive children. 2004. Paediatrica Indonesiana, 44 (1-2), 25 - 29.

[17] Siska Tambunan. Faktor-Faktor Risiko Kejadian Pneumonia pada Balita di Wilayah Kerja Puskesmas Kedungmundu Kota Semarang Tahun 2013. Jurnal. Fakultas Kesehatan. Universitas Dian Nuswanto: Semarang. 2013.

[18] Domili MFH, Nontji W, Kasim UNA. Faktor-Faktor yang berhubungan dengan kejadian Pneumonia (skripsi). 
Gorontalo: Universitas Negeri

Gorontalo; 2012.

[19] Arifin, Siregar. Pemberian Asi Ekslusif dan Faktor-Faktor Yang Mempengaruhinya. Fakultas Gizi Kesehatan Masyarakat: Sumatra Utara. 2004.http://library.usu.ac.id/download/fk $\mathrm{m} / \mathrm{fkm}$-arifin4.pdf.

[20] Undang-Undang Republik Indonesia Nomor 36 tentang Kesehatan. 2009. Jakarta.

[21] WHO dan UNICEF. The Forgotten Killer of Children. New York: WHO. 2006.

[22] Widarini, dkk. Hubungan Pemberian ASI Eksklusif Dengan Kejadian ISPA Pada Bayi di Puskesma Megwi II tahun 2009. Fakultas Ilmu Kesehatan Masyarakat. Universitas Udayana: Bali. 2009.

[23] Novianto, Fajar Ardi, dkk. Hubungan Riwayat BBLR Dengan Insidensi Pneumonia Pada Bayi Kurang Dari 2
Bulan Di RSUP Dokter Soeradji Tirtonegoro Pada Tahun 2011-212. Universitas Islam Indonesia: Yogyakarta. 2012.

[24] Ranny, Liviandari Ranantha. Hubungan Antara Karakteristik Balita Dengan Kejadian Ispa Pada Balita Di Desa Gandon Kecamatan Kaloran Kabupaten Temanggung. Skripsi,fakultas kesehatan. Universitas Dian Nuswantoro Semarang.2014.http://eprints.dinus.ac.id/ id/eprint/6715

[25] Kosim, M. Sholeh. et. Al. Buku ajar Neonatologi. IDAI. Jakarta. 2008.

[26] Sari, Annisa Novita. Analisis Faktor Risiko Intrinsik yang Berhubungan Dengan Pneumonia Pada Anak Balita di Wilayah Kerja Puskesmas Andalas Kota Padang. Jurnal Kesehatan: Stikes Syedza Saintika Padang. 2016. https://syedzasaintika.ac.id/jurnal/index. $\mathrm{php} / \mathrm{medika/article/view/38}$

[27] Rikerdas. 2013. Balitbang. Depkes RI. 